\section{Profilul psihoemoțional al tânărului activ social}

The psycho-emotional profile of the young social active

Maria Pleşca, doctor în psihologie, conferențiar universitar, Catedra de psihologie, Facultatea de Psihologie și Psihopedagogie Specială, UPS Ion Creangă, Chişinău

\section{CZU: 159.922.8/.9}

\section{Rezumat}

Activitatea socială a tânărului se axează pe două aspecte importante: trăsăturile de personalitate și cele afective. Activitatea socială se modelează din datele naturale și caracteristicile persoanei, care au fost formate și dezvoltate pe parcursul educaţional, prin instruire și practicare. $\mathrm{Cu}$ alte cuvinte, ea arată calitatea, modul în care o persoană se referă la mediul social și modul în care aceasta este în măsură să rezolve problemele (atât proprii, cât și ale altor oameni). Pentru a reliefa profilul psihoemoțional și caracteristicile adolescenților activi, am realizat o cercetare cu caracter constatativ. Analiza rezultatelor sondajului ne-a permis să determinăm raportul cantitativ al conţinutului, caracteristicile emoționale și evaluative ale reprezentărilor care compun imaginea unei persoane active în plan social.

Cuvinte-cheie: trăsături de personalitate, adolescent, activitate socială, profil afectiv, emoție, reprezentare socială.

\section{Abstract}

The social activity of the young man focuses on two important aspects: personality traits and affective ones. The social activity is considered to be modeled from the natural data and characteristics of the person who were trained and developed during the education, education, training and practical processes. In other words, it shows the quality, the way in which a person refers to the social environment and the way he is able to solve the problems (both his own and his other people's). In order to highlight the psycho-emotional profile and the characteristics of the active adolescents, we conducted research with a definitive character. The analysis of the results of the survey allowed us to determine the quantitative report of the content, the emotional and evaluative characteristics of the representations that compose the image of a person active in the social plane.

Keywords: personality traits, adolescent, social activity, affective profile, emotion, social representation. 
Activitatea socială poate fi abordată din două perspective principale. La început, ca trăsături de personalitate, după cum menționează Ș. Ionescu [2, p. 12]. Activitatea socială, sub acest aspect, reprezintă îmbinarea datelor naturale cu caracteristicile care au fost formate și dezvoltate în procesul educaţional, de dezvoltare și activități practice [1, p. 108; 4, p. 34]. I. Neacşu susţine că activitatea socială arată calitatea, modul în care o persoană se referă la mediul social și modul în care aceasta este aptă să rezolve problemele (atât personale, cât și ale altor oameni) [5, p.48]. M. Golu, G. Matthews, Ian J. Deary, M.C. Whiteman au elaborat altă accepțiune, conform căreia activitatea presupune implicarea cantitativă și calitativă a individului într-un sistem existent şi funcțional al relațiilor sociale [1, p. 102; 4, p.45].

Tema activităţii sociale a individului, care poate fi definită drept capacitatea unei persoane de a produce transformări sociale semnificative în lume, bazate pe însușirea valorilor culturale și pe unitatea viziunii și activității asupra lumii, prezintă un interes deosebit și suscită interes științific în rândul cercetătorilor din domeniul psihologiei [3, pp. 579-603].

Pentru a reliefa profilul psihoemoțional și caracteristicile adolescenților social activi, am realizat o cercetare cu caracter constatativ. Studiul a implicat liceeni și studenți din mai multe universități din orașul Chișinău. Subiecților din eșantionul de cercetare (care a inclus 200 de persoane), format din trei grupuri de respondenți (implicaţi în activități de sport şi turism, în activități cu profil umanitar (voluntari) și cu activitate socială incertă), le-a fost solicitat să continue enunţul $O$ persoană activă este... [6, p. 98].

Analiza rezultatelor sondajului ne-a permis să determinăm raportul cantitativ al conținutului, caracteristicile emoționale și evaluative ale reprezentărilor care compun imaginea unei persoane active în plan social.

În funcție de tipurile de activităţi sociale ale respondenților, frecvența mediilor a fost distribuită după cum urmează: la cei cu activități sportive și turistice, predomină, în proporție de 90\%, caracteristicile semnificative; la 5\%, cele emoționale și caracteristicile de conținut sunt atestate la 5\%; la cei cu activitate umanistă, caracteristicile semnificative prevalează la 73,9\%, cele emoționale - la 17,4\%, iar cele de conținut - la 8,7\%; la subiecții cu activitate incertă, caracteristicile semnificative se atestă în proporție de $68,1 \%$, cele emoționale - la 4,2\%, iar caracteristicile de conținut - la 27,6\% (vezi figura 1). Datele obținute ne demonstrează prevalarea caracteristicilor esențiale în raport procentual la grupul adolescenților ce 
practică activității sportive și turistice, a celor emoționale - în grupul adolescenților ce practică activităţii umaniste și caracteristicile evaluative sunt atestate în grupul celor cu activitate socială nedeterminată.

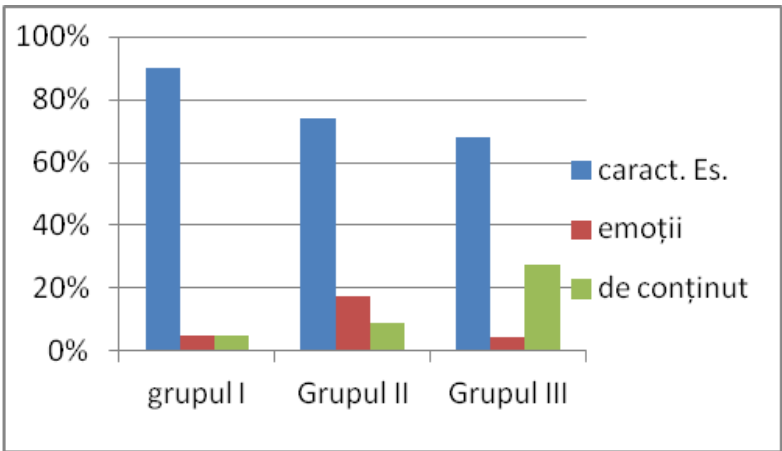

Fig. 1. Frecvența mediilor în funcție de tipurile de activități sociale ale respondenților

Acest lucru indică faptul că în grupul de adolescenți care practică activități sportive și turistice reprezentările studiate sunt caracterizate mai mult de indicatorii de valoare și semantici și mai puțin de cei emoționali, în comparație cu alte grupuri.

$\mathrm{La}$ reprezentanții grupului $\mathrm{cu}$ activitate socială umanistă, în comparație cu alți respondenți, predomină ideea unei persoane active, care este mai mult asociată cu emoțiile. Acestea sunt în principal caracteristici ale emoțiilor pozitive (,amuzant”, „vesel”, „pozitiv”).

Caracteristicile de conținut sunt mai mult exprimate în reprezentările subiecților cu activitate nedeterminată, ceea ce îi caracterizează ca având un model specific al unei persoane active, în comparație cu alţi respondenți, după acest criteriu.
Pe lângă diferențierea caracteristicilor în funcție de criteriul calitativ, s-a făcut o distribuție a datelor în funcție de grupurile semantice prezentate respondenților, ceea ce a făcut posibilă calcularea frecvenței distribuției reprezentărilor în diferite grupuri (indicate mai jos între paranteze). Au fost diferențiate cinci grupuri semantice de reprezentări: caracteristici dinamice de personalitate, indicatori de creștere a imaginii de sine, indicatori care caracterizează persoana ca membru al unui grup social.

Tabelul 1. Distribuția caracteristicilor semantice

\begin{tabular}{|c|c|c|c|c|c|}
\hline $\begin{array}{c}\text { Activități } \\
\text { sociale }\end{array}$ & $\begin{array}{l}\text { Trăsături de } \\
\text { personalitate }\end{array}$ & $\begin{array}{l}\text { Dinamismul } \\
\text { personalității }\end{array}$ & $\begin{array}{l}\text { Membru } \\
\text { al unui } \\
\text { grup } \\
\text { social }\end{array}$ & $\begin{array}{l}\text { Activitatea } \\
\text { ca proces }\end{array}$ & Stări \\
\hline $\begin{array}{l}\text { Sportive și } \\
\text { turistice }\end{array}$ & 0,3 & 0,25 & 0 & 0,05 & 0,4 \\
\hline Umanistă & 0,35 & 0,2 & 0,2 & 0,11 & 0,15 \\
\hline Nedeterminată & 0,23 & 0,23 & 0,21 & 0,17 & 0,15 \\
\hline
\end{tabular}

După cum se poate observa din tabelul 1, cea mai mare distribuție de frecvență a caracteristicilor de personalitate este atestată la respondenții angajați în activități umanistice $(0,35)$, în comparație cu adolescenții din celelalte grupuri de activitate. Probabil, acest lucru se datorează orientării sociale a activităților adolescenților activi în sfera umanistă, care, la rândul său, determină concentrarea atenției asupra trăsăturilor de personalitate.

Reprezentanții sferei umaniste de activitate încearcă să compileze personajul unei persoane folosind următoarele 
concepte: „vesel” $(0,11), \quad$,responsabil” $(0,06)$, , vesel” $(0,04)$ și ,inteligent” $(0,02)$. Indicatorii care caracterizează dinamica dezvoltării și creșterea calitativă a unei persoane se regăsesc mai des în grupul adolescenților care preferă activităţi sportive şi turistice $(0,25)$. Evident, acest tip de activitate implică dorința de autodezvoltare, consolidare fizică și în acest sens se poate presupune că imaginea unei persoane active la reprezentanții acestui grup este formată, inclusiv luând în considerare propriile activităţi şi calităţi inerente în sine (,dezvoltate” $(0,1)$, ,autoperfectare” $(0,05)$, „ştie de ce are nevoie" $(0,05)$, ,interesat de tot" $(0,05)$.

Următorul grup semantic, care include enunțuri ce caracterizează o persoană ca membru eficient al grupului, are cea mai mare distribuție de frecvență în grupul adolescenților cu activități sociale nedeterminate. La ei, predomină următoarele afirmații, care descriu imaginea unei persoane social active: „sociabil” $(0,08)$, ,angajat în activități sociale” $(0,02)$, „lider” $(0,02)$, ,participă la viața publică” $(0,02)$.

Aceste descrieri determină în cea mai mare parte orientarea generală a activității subiecților grupului cu activități sociale nedeterminate, deoarece ei sunt orientați spre a crea și menține numeroase contacte sociale, a câștiga experiență în interacțiunea cu publicul. Cel mai probabil, această distribuție este cauzată de varietatea tipurilor de activități sociale, caracteristică grupului cu activitate nedeterminată, pentru care calitatea interacțiunii cu echipa este primordială (activitate politică, activitate culturală, organizare și participare la activități recreative).

Următorul grup semantic combină caracteristicile proces-activitate care sunt inerente grupului cu activitate socială nedeterminată $(0,17)$. Conceptele selectate de respondenți în legătură cu acest grup semantic nu indică un tip și un domeniu de activitate specific, fapt care se datorează inexactității în determinarea ariei de activitate socială caracteristică subiecților. Acestea sunt concepte precum ,inițiator” $(0,06)$, „benefic” $(0,04)$, „participarea la evenimente" $(0,02)$, ,a trăi o viață deplină" $(0,02)$.

Ultimul grup semantic include enunțuri care caracterizează starea psihoemoțională a unei persoane active, potrivit respondenților. În urma analizei datelor de distribuție a frecvențelor, s-a stabilit că aceste afirmații sunt mai caracteristice reprezentanţilor grupului de activități sociale sportive și turistice, în comparație cu alte grupuri de activități $(0,4)$. Expresiile menționate de subiecți indică starea individului în procesul de activitate: ,activ” $(0,15)$, „reuşit” $(0,1)$, „energetic” $(0,1)$, „sănătos” $(0,05)$. 
Caracteristicile descrise anterior nu afectează calitățile personale ale subiectului, care sunt asociate cu concentrarea atenției pe activități sportive și turistice. Într-adevăr, de regulă, un subiect angajat în astfel de activități nu urmărește un obiectiv specific. Or, sunt importante procesul de activitate în sine, dinamica dezvoltării și starea psihologică a subiectului, care se instalează după antrenamente și evenimente sportive.

Astfel, analiza datelor studiului ne-a permis să formulăm următoarele concluzii:

1. Respondenții care sunt membri ai unui grup cu activitate nedeterminată, în declarațiile lor, definesc o persoană activă ca element social care interacționează în primul rând cu mediul social.

2. Adolescentul activ în domeniul sportului și turismului reprezintă într-o mai mare măsură $\quad$ o persoană activă prin caracteristicile și deprinderile sale dinamice și probează într-o măsură mai mică trăsăturile de personalitate.

3. Orientarea asupra activității umanitare probează într-o măsură mai mare trăsăturile de personalitate.

4. Imaginea unei persoane active la toți respondenții este însoțită, în principal, de experiențe și aprecieri afective pozitive.

5. Astfel, conținutul de idei despre o persoană activă este asociat cu tipul preferat de activitate socială.

\section{Bibliografie}

1. GOLU, M. Dinamica personalității. București: Paideia, 2005.

2. IONESCU Ș. Tratat de reziliență asistată. București: Trei, 2013.

3. KAUSHAL R., KWANTES C.T. The role of culture and personality in choice of conflict management strategy. În: International Journal of Intercultural Relations. V. 30, 2006, pp. 579-603.

4. MATTHEWS G., DEARY I, WHITEMAN M.C. Psihologia Personalităţii. Trăsături, Cauze, Consecințe. Iași: Polirom, 2012.

5. NEACŞU I. Introducere în psihologia educaţiei şi a dezvoltării. Iaşi: Polirom, 2010 .

6. TUFEANU M. Provocări în dezvoltarea adolescenţilor în contextul schimbărilor sociale de la începutul mileniului al III-lea. Psihologie. Revistă ştiinţifico-practică (Editată de Asociaţia Psihologilor Practicieni din Republica Moldova), 2012, nr. 3. 